\title{
PENINGKATAN AKTIVITAS BELAJAR PESERTA DIDIK PADA PEMBELAJARAN IPA MENGGUNAKAN LKPD SECARA DARING DI SMPN 248 JAKARTA
}

\author{
HERMA YUNIS \\ Pascasarjana PMIPA, Universitas Indraprasta PGRI, Jakarta \\ Email: hermayunis248@gmail.com
}

\begin{abstract}
ABSTRAK
Penelitian ini bertujuan untuk meningkatan hasil belajar peserta didik menggunakan LKPD. Proses pembelajaran secara daring menyebabkan peserta didik abai terhadap tugas yang diberikan, kurang menguasai materi IPA dan kehilangan fokus dalam belajar. Penelitian tindakan kelas ini dirancang dalam dua siklus. Tindakan yang dilakukan dengan melakukan observasi saat kegiatan belajar dengan indikator meliputi: tingkat kehadiran, keaktifan menjawab pertanyaan guru dan pengumpulan tugas tepat waktu. Cakupan materi yang diberikan pada siklus I adalah Pengukuran dan pada siklus II adalah Sifat Larutan. Subyek penelitian ini adalah Peserta Didik Kelas VII D SMPN 248 Jakarta tahun ajaran 2021/2022 sebanyak 35 orang. Hasil Penelitian Tindakan Kelas didapatkan dalam dua siklus, telah terjadi peningkatan aktivitas belajar dilihat dari peningkatan kehadiran mencapai $100 \%$ pada siklus ke II dari $77,14 \%$ di siklus I. Keaktifan peserta didik dalam menjawab pertanyaan meningkat dari $8,6 \%$ di siklus I menjadi $28,57 \%$ di siklus ke II. Peningkatan keaktivan peserta didik dalam mengumpulkan tugas meningkat dari $68,57 \%$ di siklus I menjadi $85,71 \%$ di siklus II.
\end{abstract}

Kata Kunci : LKPD, Aktifitas Belajar, Google Classroom

\section{ABSTRACT}

This study aims to improve student learning outcomes using LKPD. The online learning process causes students to ignore the assigned tasks, lack mastery of science material and lose focus in learning. This classroom action research is designed in two cycles. Actions taken by observing during learning activities with indicators include: attendance level, activeness in answering teacher questions and collecting assignments on time. The scope of the material given in the first cycle is Measurement and in the second cycle is the Properties of the Solution. The subjects of this study were 35 students of Class VII D SMPN 248 Jakarta in the 2021/2022 academic year. The results of Classroom Action Research were obtained in two cycles, there has been an increase in learning activities seen from the increase in attendance reaching $100 \%$ in the second cycle from $77.14 \%$ in the first cycle. The activeness of students in answering questions increased from $8.6 \%$ in the first cycle to $28.57 \%$ in the second cycle. The increase in student activity in collecting assignments increased from $68.57 \%$ in the first cycle to $85.71 \%$ in the second cycle.

Keywords: LKPD, Learning Activities, Google Classroom

\section{PENDAHULUAN}

Menteri Pendidikan mengeluarkan SE Nomor 4 (Kementrian Pendidikan dan Kebudayaan, 2020) tentang Pelaksanaan Kebijakan Pendidikan dalam Masa Darurat Penyebaran Covid, pada surat edaran tersebut dijelaskan proses belajar dilakukan di rumah melalui pembelajaran daring atau jarak jauh agar dapat memberikan pengalaman belajar yang bermakna untuk siswa. Kegiatan belajar mengajar mengalami perubahan dari tatap muka menjadi daring. Proses pembelajaran daring ini berlaku pada semua jenjang mulai dari PAUD hingga Perguruan Tinggi, termasuk di SMPN 248.

Menurut Sardiman (2005) dalam Dahlan, Aktivitas belajar peserta didik adalah aktivitas yang bersifat fisik ataupun mental. Dalam aktivitas belajar ini peserta didik haruslah aktif mendominasi dalam mengikuti proses belajar mengajar sehingga mengembangkan potensi yang ada pada dirinya. Proses pembelajaran dikatakan efektif bila peserta didik secara aktif ikut 
terlibat langsung dalam pengorganisasian dan penemuan informasi (pengetahuan), sehingga mereka tidak hanya menerima secara pasif pengetahuan yang diberikan oleh guru. Jenis aktivitas belajar berdasarkan Depdiknas (2004), sebagai indikator aktivitas belajar peserta didik secara individual dalam proses belajar mengajar di kelas adalah: 1. Kehadiran di kelas, 2. Ketepatan waktu mengumpulkan tugas, 3. Kelengkapan buku catatan, 4. Menyimak dan memperhatikan penjelasan, 5. Menyampaikan pendapat

Seiring berjalannya waktu, pembelajaran IPA secara daring di SMPN 248 menemukan kendala yaitu materi yang diajarkan secara daring direspon berdasarkan tingkat pemahaman yang berbeda-beda. Beberapa peserta didik dapat menangkap materi dengan cepat hanya dengan membaca, namun ada juga yang membutuhkan waktu lebih lama untuk memahami suatu materi. Selain itu guru mengalami kendala saat mengumpulkan tugas. Kurangnya pengawasan dalam kegiatan belajar secara daring membuat peserta didik kehilangan fokus. Peserta didik cenderung menunda-nunda waktu belajar dan mengumpulkan tugas. Hal tersebut tentunya menghambat tercapainya tujuan belajar di kelas.

Menurut Nugraha dan Fitri (dalam Ernawati 2019), dalam kegiatan pembelajaran, salah satu komponen yang turut menentukan kualitas dan keberhasilan pembelajaran adalah bahan ajar. Adapun salah satu bahan ajar yang sering digunakan dalam proses pembelajaran adalah LKPD (Lembar Kerja Peserta Didik). LKPD merupakan bahan ajar yang dibuat, disusun oleh guru. LKPD berisi tugas-tugas yang dikerjakan oleh siswa. LKPD sebaiknya dibuat oleh guru yang mengajar di kelas tersebut, karena hanya guru yang bersangkutan yang memahami situasi dan kondisi yang diajar.

Dijelaskan oleh Prastowo (dalam Rahmadina 2017: 6), bahwa terdapat empat poin penting yang menjadi tujuan penyusunan LKPD yaitu: 1.Menyajikan bahan ajar yang memudahkan peserta didik untuk memberi interaksi dengan materi yang diberikan. 2.Menyajikan tugas-tugas yang meningkatkan penguasaan peserta didik terhadap materi yang diberikan. 3.Melatih kemandirian belajar peserta didik. 4.Memudahkan pendidik dalam memberikan tugas kepada peserta didik. Dituliskan dalam sebuah penelitian (dalam Aini, 2012:13) dikatakan bahwa penggunaan LKPD dapat menciptakan kondisi belajar yang aktif dan kondusif kerena penggunaan LKPD ini menuntut setiap peserta didik mampu menganalisis materi pelajaran yang sedang dipelajari. Penggunaan LKPD di dalam proses pembelajaran di kelas membuat peserta didik lebih terarah dalam belajar karena di dalam LKPD susunan soal maupun tugas jelas dicantumkan.

Penulis melakukan penelitian pada siswa kelas VII D SMPN 248 Jakarta semester ganjil tahun pelajaran 2021/2022. Dalam kegiatan belajar di kelas VII D SMP 248 penulis menemukan peserta didik kurang menguasai materi IPA yang diberikan dan kehilangan fokus dalam belajar, hal ini ditandai dengan hasil belajar yang kurang memuaskan, selain itu peserta didik banyak yang terlambat mengumpulkan tugas akibat menunda-nunda pengerjaannya. Berdasarkan pengamatan tersebut, penulis memberi judul artikel ini yaitu "Meningkatkan aktivitas Belajar Peserta Didik pada Pembelajaran IPA menggunakan LKPD Secara Daring di SMPN 248 Jakarta".

\section{METODE PENELITIAN}

Penelitian ini merupakan penelitian tindakan kelas yang bertujuan untuk meningkatkan aktivitas belajar peserta didik pada pembelajan IPA di SMPN 248 Jakarta. Tindakan yang akan dilakukan adalah dengan melakukan observasi terhadap aktivitas belajar peserta didik. Subjek penelitian ini adalah peserta didik kels VII D SMPN 248 Jakarta yang berjumlah 35 orang, terdiri atas 15 orang laki-laki dan 20 orang perempuan.

Observasi dilakukan bersamaan dengan proses pembelajaran dengan memberikan ceklis mengenai tingkah laku peserta didik secara indivdu pada bulan Juli sampai dengan September tahun 2021. Observasi dilakukan untuk mengetahui tingkat keaktifan peserta didik dalam proses pembelajaran dengan indikator meliputi: tingkat kehadiran, keaktifan menjawab pertanyaan guru dan pengumpulan tugas tepat waktu. 


\section{HASIL DAN PEMBAHASAN}

\section{Hasil}

Siklus 1

Pelaksanaan tindakan dilakukan oleh pengajar sekaligus sebagai peneliti. Kegiatan pembelajaran dimulai dengan menyampaikan tujuan pembelajaran diikuti dengan apersepsi. Guru memberikan pertanyaan untuk mengukur pemahaman awal peserta didik tentang Besaran dan Satuan. Setelah itu guru menayangkan video pembelajaran Besaran Pokok dan Besaran Turunan untuk menarik perhatian siswa. Setelah guru memberikan ulasan materi peserta didik diberikan LKPD Pengukuran untuk kegiatan belajar secara mandiri.

Peneliti melakukan penilaian dengan cara observasi yang mengacu pada rubrik penilaian aktivitas belajar peserta didik yang dilakukan selama proses pembelajaran, dapat dilihat dari kehadiran peserta didik saat pembelajaran, keaktifan respon peserta didik saat tanya jawab, dan pengumpulan tugas mandiri pada LKPD. Peneliti juga menyampaikan dan membahas rubrik yang akan digunakan dalam setiap proses penskoran. Berdasarkan cara penilaian yang dilakukan tersebut akan diperoleh hasil berupa nilai aktivitas belajar peserta didik.

Hasil pembelajaran siklus I meliputi kehadiran peserta didik saat pembelajaran yang direkam dalam Google Classroom, keaktifan peserta didik bertanya dan menjawab pertanyaan pada pertemuan virtual melalui aplikasi zoom dan pengumpulan tugas mandiri dalam bentuk LKPD di google classroom dapat dipaparkan sebagai berikut.

Tabel. 1. Hasil Aktivitas Belajar Siklus 1

\begin{tabular}{|cccc|}
\hline Aktivitas & Kehadiran & Keaktivan & Pengumpulan tugas \\
\hline Jumlah & $\mathbf{2 7}$ siswa & 3 siswa & 24 siswa \\
\hline Persentase & $\mathbf{7 7 , 1 4 \%}$ & $\mathbf{8 , 6} \%$ & $\mathbf{6 8 , 5 7 \%}$ \\
\hline
\end{tabular}

Analisis terhadap aktivitas belajar peserta didik pada siklus pertama menunjukkan bahwa kehadiran peserta didik mencapai $77,14 \%$, peserta didik yang menjawab pertanyaan sebanyak $8,6 \%$ dan siswa yang mengumpulkan tugas sebesar $68,57 \%$.

Berdasarkan temuan dari kegiatan observasi yang dilakukan selama pelaksanaan siklus I, maka diadakan upaya untuk memperbaiki proses tindakan pada siklus berikutnya sehingga diharapkan kendala-kendala yang ditemukan selama proses pelaksanaan siklus I dapat diatasi. Adapun upaya-upaya yang dilakukan adalah sebagai berikut. 1) Sebelum melaksanakan tindakan siklus II, peneliti memberikan penekanan terhadap peserta didik mengenai pembelajaran yang digunakan dan penilaian yang akan dilakukan. Peneliti menyampaikan bahwa selain dilakukan penilaian terhadap pemahaman konsep untuk dimasukkan ke dalam nilai harian peserta didik, juga akan diadakan penilaian aktivitas belajar yang salah satunya meliputi kehadiran, keaktifan dalam mengikuti pelajaran dan pengumpulan tugas tepat waktu. Makin aktif peserta didik di kelas maka makin besar nilai yang akan diperoleh. Selain itu, peneliti memberikan kesempatan lebih banyak pada peserta didik untuk bertanya dan mengajukan pendapat mengenai materi yang dibahas selama proses pembelajaran berlangsung. Menunjuk beberapa peserta didik yang kurang aktif dalam berpendapat untuk mencoba mengajukan pendapat sesuai dengan pengetahuannya. Tujuannya, agar peserta didik tersebut menjadi lebih berani dalam mengungkapkan pendapatnya selama proses pembelajaran berlangsung.

\section{Siklus II}

Pelaksanaan tindakan siklus II disesuaikan dengan hasil refleksi pada siklus I, dengan melakukan beberapa tindakan perbaikan seperti yang telah diuraikan pada hasil refleksi siklus I di atas. Hasil pembelajaran siklus II meliputi aspek aktivitas belajar yang dipaparkan sebagi berikut. Pelaksanaan tindakan dilakukan oleh pengajar sekaligus sebagai peneliti. Kegiatan 
pembelajaran dimulai dengan menyampaikan tujuan pembelajaran diikuti dengan apersepsi. Guru memberikan pertanyaan untuk mengukur pemahaman awal peserta didik tentang Sifat Larutan. Setelah itu guru menayangkan video pembelajaran Sifat Larutan untuk menarik perhatian peserta didik. Setelah itu guru memberikan ulasan materi. LKPD Sifat Larutan (Asam Basa) diberikan untuk kegiatan mandiri.

Tabel.2. Hasil Aktivitas Belajar Siklus II

\begin{tabular}{|cccc|}
\hline Aktivitas & Kehadiran & Keaktifan & Pengumpulan Tugas \\
\hline Jumlah & 35 siswa & 10 siswa & 30 siswa \\
\hline Persentase & $100 \%$ & $28,57 \%$ & $85,71 \%$ \\
\hline
\end{tabular}

Analisis terhadap aktivitas belajar peserta didik pada siklus II menunjukkan bahwa kehadiran peserta didik mencapai $100 \%$, peserta didik yang menjawab pertanyaan sebanyak $28,57 \%$ dan siswa yang mengumpulkan tugas sebesar $85,71 \%$.

Adanya peningkatan persentase hasil aktivitas belajar menunjukkan bahwa kegiatan pembelajaran pada siklus II sudah berjalan dengan baik. Pendekatan dan bimbingan yang diberikan membuat peserta didik lebih berani bertanya dan mengemukakan pendapatnya. Peserta didik juga sudah bisa menghargai setiap pendapat yang diajukan, hal ini dapat menghilangkan rasa takut dan malu pada mereka ketika ingin memberikan suatu pendapat. Aktivitas peserta didik ketika melakukan pembelajaran sudah meningkat. Baik dari kehadiran peserta didik maupun pengumpulan tugas yang tepat waktu. Hasil dari refleksi ini menunjukkan bahwa dengan perbaikan yang dilakukan terjadi peningkatan kualitas dari segi kegiatan proses belajar mengajar di kelas.

Perkembangan hasil penelitian antara siklus I dan siklus II dapat dilihat kembali pada hasil belajar peserta didik selama siklus I dan siklus II. Perbandingan nilai hasil aktivitas belajar peserta didik antara siklus I dengan siklus II adalah sebagai berikut.

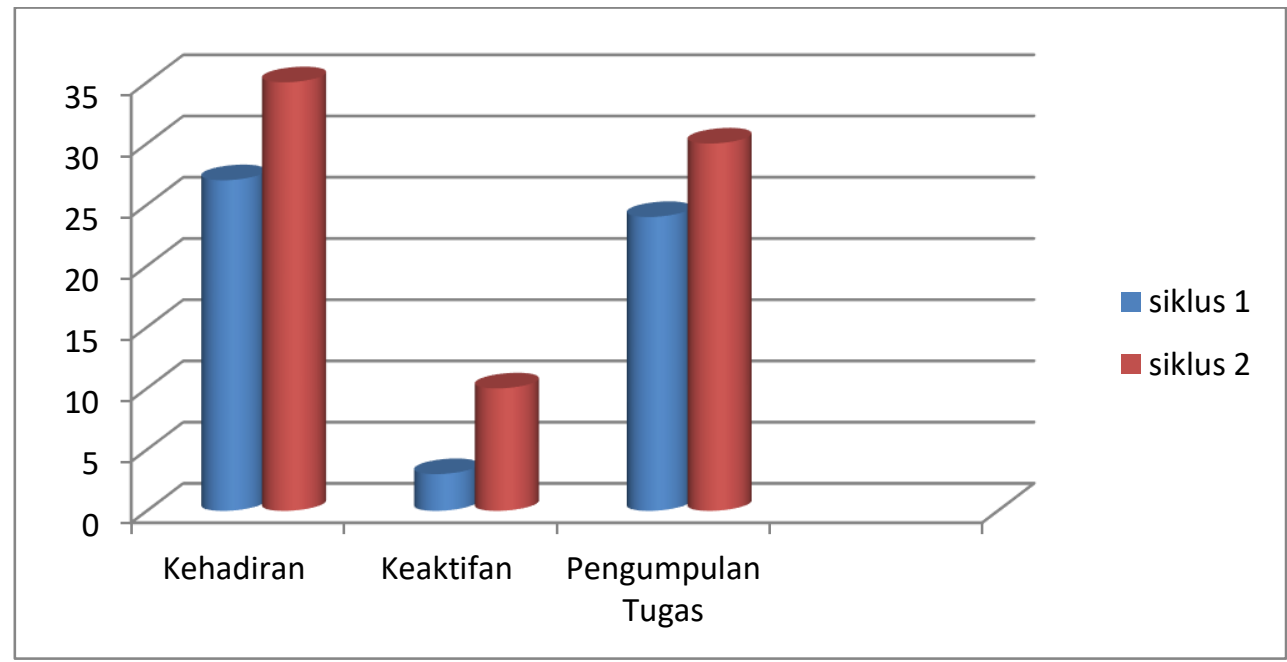

Gambar 1. Grafik Profil Aktivitas Belajar

Berdasarkan hasil penelitian dalam dua siklus, menunjukkan telah terjadi peningkatan aktivitas belajar dilihat dari peningkatan kehadiran mencapai $100 \%$ pada siklus ke II dari $77,14 \%$ di siklus I. Keaktifan peserta didik dalam menjawab pertanyaan meningkat dari 8,6\% di siklus I menjadi $28,57 \%$ di siklus ke II. Peningkatan keaktivan peserta didik dalam mengumpulkan tugas meningkat dari $68,57 \%$ di siklus I menjadi $85,71 \%$ di siklus II.

\section{Pembahasan}

Berdasarkan hasil penelitian tersebut menunjukkan bahwa pembelajaran menggunakan LKPD dapat meningkatkan aktivitas belajar. Di dalam pembelajaran peserta didik adalah subyek yang memiliki kemampuan untuk secara aktif mencari, mengolah, mengkonstruksi, dan menggunakan pengetahuan. Menurut Hosnan (dalam Marsya,dkk, 2016: 11) pembelajaran aktif 
merupakan proses kegiatan belajar mengajar yang subjek didiknya terlibat secara intelektual dan emosional sehingga ia betul-betul berperan dan berpartisipasi aktif dalam kegiatan belajar mengajar. Hal ini sesuai dengan penelitian yang dilakukan oleh Marsa,dkk (2016) bahwa LKPD dapat meningkatkan aktivitas belajar peserta didik karena pendekatan ini merupakan pembelajaran yang berpusat pada peserta didik yang pada dasarnya berusaha untuk memperkuat dan memperlancar stimulus dan respons peserta didik dalam pembelajaran, sehingga proses pembelajaran menjadi hal yang menyenangkan.

Penggunaan LKPD dalam kegiatan pembelajaran bertujuan untuk memudahkan guru saat proses belajar di kelas dan memudahkan peserta didik dalam memahami konsep-konsep materi yang dipahaminya dengan baik. Penggunaan LKPD menuntut peserta didik untuk lebih aktif dalam pembelajaran tersebut. Sesuai dalam penelitian Aini, Rochman N (2011) bahwa penggunaan LKPD membuat peserta didik lebih bertanggung jawab dengan tugas yang diberikan dan membuat peserta didik lebih aktif dalam belajar karena guru diposisikan sebagai fasilitator. LKPD membantu peserta didik memetakan materi pembelajaran sehingga lebih mudah dipahami.

Menurut penelitian Syarif, dkk (2021) didapatkan bahwa penggunaan LKPD meningkatkan secara keseluruhan aktivitas belajar peserta didik. Hal ini dikuatkan dengan beberapa perubahan tingkah laku peserta didik seperti meningkatnya tingkat perhatian dan kefokusan mereka saat belajar. Aktivitas peserta didik yang dulunya di luar pembelajaran dominan seperti melamun dan mengusik temannya sekarang sudah bisa diminimalisir.

\section{KESIMPULAN}

Berdasarkan hasil penelitian disimpulkan bahwa LKPD dapat meningkatkan aktivitas belajar peserta didik kelas VII D SMPN 248 Jakarta pada tahun ajaran 2021-2022. Hal ini terbukti dari peningkatan kehadiran mencapai $100 \%$ pada siklus ke II dari $77,14 \%$ di siklus I. Keaktifan peserta didik dalam menjawab pertanyaan meningkat dari $8,6 \%$ pada siklus I menjadi $28,57 \%$ di siklus ke II.

\section{DAFTAR PUSTAKA}

Aini, Rochmah N. (2011). Upaya Meningkatkan Aktivitas Belajar siswa melalui penggunaan LKS dalam Pelajaran IPS di kelas VIII MTS An Nur Pekan Baru. Skripsi. Fakultas Keguruan dan Ilmu Pendidikan. Universitas Riau. Pekan Baru.

Arikunto, Suharsimi. (2002). Penelitian Tindakan Kelas. Jakarta : Bumi aksara

Ernawati, Yeni. (2019). Pengembangan Lembar Kerja Peserta Didik (LKPD) pada Materi Teks Fabel Berbasis Saintifik untuk Siswa SMP Kelas VIII. Jurnal DIKSA from https://ejournal.unib.ac.id/index.php/jurnaldiksa/article/view/9982

Dahlan, Ahmad. Definisi Aktivitas Belajar. https://eurekapendidikan.com/definisi-aktivitasbelajar. Diakses 18/10/2021

Marsa., Yusminah Hala., A. Mushawwir Taiyeb. (2016). Pengaruh Penggunaan Lembar Kerja Peserta Didik Berbasis Pendekatan Ilmiah Terhadap Aktivitas dan Hasil Belajar IPA Biologi Kelas VII Peserta Didik SMP Negeri 2 Watampone Jurnal Sainsmat, Maret 2016, Halaman 42-57 Vol. V, No. 1 ISSN 2086-6755 from: http://ojs.unm.ac.id/index.php/sainsmat

Rahmadina,S., Yanzi,H., Nurmalisa,Y., (2017). Persepsi Guru Terhadap Penggunaan Lembar Kegiatan Peserta Didik Di Smp Negeri 3 Terbanggi Besar Lampung Tengah. FKIP UNILA.

Riduwan. (2009). Pengantar Statistika Sosial. Bandung: Alfabeta.

Syarif, Andi Fajrin, dkk (2021). Pengembangan LKPD Berbasis Model Kooperatif Think PairShare Untuk Meningkatkan Aktivitas Belajar. Jurnal Penelitian Pendidikan dan Pengajaran Matematika. vol. 7 no. 2, pp. $79-86$ 